Долгополов Кирилл Андреевич

кандидат юридических наук, доцент, и. о. заведующего кафедрой

уголовного права и процесса

Северо-Кавказского федерального университета

\section{ФАКТОРЫ, КОМПЕНСИРУЮЩИЕ ДЕСОЦИАЛИЗАЦИЮ ИНДИВИДА В МЕСТАХ ЛИШЕНИЯ СВОБОДЫ}

Аннотация:

В статье рассмотрены вопросы, связанные с deсоциализацией осужденных в местах лишения свободы и факторами, ее компенсирующими. Объектом исследования является процесс десоциализации осужденного к отбыванию уголовного наказания, связанного с лишением свободы, предметом - совокупность основных факторов, влияние которых на осужденного компенсирует его десоциализацию во время отбывания наказания. Выделены факторы, позволяющие сделать десоциализацию осужденного к лишению свободы индивида менее глубокой. Делается вывод о необходимости использования данных факторов для изменения характера работы с осужденными в направлении их перевоспитания и исправления. Выдвигается ряд предложений по формированию системы работы с заключенными с целью компенсации десоциализации в местах лишения свободы, что позволит сделать процесс перевоспитания и исправления более эффективным.

Ключевые слова:

места лишения свободы, десоциализация, заключенный, компенсация десоциализирующего влияния
Dolgopolov Kirill Andreevich

PhD in Law, Associate Professor, Acting Head of Criminal Law and Procedure Department

North Caucasus Federal University

THE FACTORS COMPENSATING FOR DESOCIALIZATION OF THE INDIVIDUAL IN PLACES OF DETENTION
Summary:

The study considers issues related to desocialization of prisoners in places of detention and the factors compensating for it. The object of the research is the process of desocialization of a prisoner serving a custodial sentence, the subject is a set of main factors, which influence on a prisoner compensates for his desocialization during the serving of the sentence. The factors that can make desocialization of the individual serving a custodial sentence less profound are highlighted. It is concluded that it is necessary to use these factors to change the work with prisoners in the direction of their re-education and reformation. A number of suggestions are put forward to form a system of work with prisoners in order to compensate for desocialization in places of detention. It will make the process of prisoners' re-education and reformation more effective.

Одной из серьезных проблем российского общества является рецидивная преступность. Согласно результатам социологических исследований, 30 \% тех, кто отбывал наказание в местах лишения свободы, вновь привлекаются к ответственности за совершение преступления [1], т. е. по некоторым причинам в отношении них система назначения и исполнения наказания оказалась неэфффективной. Анализируя данные о рецидивной преступности, можно утверждать, что в деятельности исправительной системы существуют проблемы, требующие незамедлительного решения.

Одна из главных причин рецидивной преступности - это то, что во время отбывания наказания человек подвергается влиянию ряда факторов, вызывающих изменения в его психике и поведении. Такими факторами в первую очередь выступают нормы тюремного «закона», продолжительное пребывание в изоляции от общества, требования режима и администрации исправительного учреждения. Это приводит к десоциализации индивида и осложняет процесс его исправления.

Проблему десоциализации в местах лишения свободы можно рассмотреть в рамках концепции Э. Гоффрмана. Он ввел понятие «тотального института», погружающего человека в определенные условия, в которых его десоциализация может быть настолько серьезной, что последующая ресоциализация после освобождения из заключения окажется поверхностной [2, с. 38]. Приведенной характеристике в полной мере соответствуют места лишения свободы.

При этом следует отметить, что учреждения, обеспечивающие отбывание осужденными назначенного судом наказания, именуются исправительными. В отечественной системе исполнения наказаний исправление заключенных основано на привлечении их к труду. При этом системная работа с осужденными, которая бы компенсировала десоциализацию и готовила их к освобождению, в местах лишения свободы отсутствует [3, с. 98].

Между тем система такой работы с осужденными необходима. Общество должно быть заинтересовано в ресоциализации человека, освободившегося из мест лишения свободы, его возврате к нормальной жизни. К.В. Корольков указывает на негативное отношение заключенных к 
системе исправительных воздействий, которая сформировалась в советское время [4, с. 64]. Учитывая, что эта система с советских времен не претерпела кардинальных изменений, можно говорить о том, что прежним осталось и отношение осужденных к ней. Следовательно, десоциализация заключенных в целом находится на прежнем уровне, поэтому строить указанную систему нужно, начав с изменений в работе пенитенциарных учреждений в области мер по перевоспитанию и исправлению осужденных.

Т. Лукман и П.Л. Бергер в процессе социализации выделяют интернализацию - процесс глубокого усвоения индивидом ценностей и норм конкретного сообщества [5]. В нашем случае десоциализация индивида является результатом усвоения им ценностей и норм тюремного сообщества. Отсюда следует, что для построения указанной системы работы с заключенными необходимо определить фракторы, влияние которых компенсирует десоциализацию в местах лишения свободы.

Негативное отношение осужденных к системе воспитательно-исправительных воздействий фрормируется прежде всего под воздействием того, что связано с их пребыванием в исправительном учреждении. Поэтому факторы, влияние которых может компенсировать десоциализацию осужденных, в сознании индивида должны вызывать ассоциации с отношениями в обществе, которое он вынужденно покинул.

Таким фактором, прежде всего, являются родственные и дружеские связи. Все материальные и психологические тяготы отбывания наказания значительно легче переносятся человеком, ощущающим поддержку и заботу близких людей на свободе [6, с. 68]. С другой стороны, отсутствие влияния данного фактора усиливает десоциализацию. Так, А.Н. Олейник в своем исследовании указывает, что 20,9 \% лиц, вновь совершивших преступление, находились в разводе, 50,2 \% никогда не были женаты (замужем) [7]. Таким образом, увеличение степени влияния данного фактора на заключенного снижает его подверженность десоциализации в местах лишения свободы.

А.Н. Олейник отмечает существование френомена тотального недоверия среди людей, находящихся в местах лишения свободы. При этом исследователь указывает, что «отсутствие доверия вовсе не означает, что заключенные рассматривают эту норму как нечто ненужное и излишнее в повседневной жизни. Именно норма доверия находится во главе угла списка основ, на которых должно базироваться общество в России» [8]. Знаменитая тюремная поговорка «Не верь, не бойся, не проси» как раз свидетельствует о дефиците доверия в местах заключения. Также, по словам заключенных, минимизация общения в тюремном сообществе в области сообщения информации личного характера связана именно с проблемой недоверия [9, с. 71]. Поэтому влияние фактора доверия в местах лишения свободы может в значительной степени компенсировать десоциализацию.

Еще одним фактором, компенсирующим десоциализацию в местах лишения свободы, выступает образование [10, с. 77]. Нынешней пенитенциарной системе досталась система образования, созданная во времена СССР, когда ее организация была на достаточно высоком уровне. Это позволяет успешно поддерживать ее развитие и на современном этапе [11]. В частности, по данным ФСИН, в учебных заведениях при исправительных колониях получали образование на разном уровне в 2016 г. около 60 тыс. осужденных [12], в 2018 г. - приблизительно 70 тыс. [13].

Общее девятилетнее образование нормативно закреплено в исправительных учреждениях российским законодательством [14], что делает обязательным обучение в школе осужденных, не достигших возраста тридцати лет и не имеющих основного общего образования.

А.С. Макаренко не представлял педагогического процесса исправительно-трудовых учреждений без средней школы: «...перевоспитание, настоящее полное перевоспитание, гарантирующее от рецидивов, возможно только при полной средней школе» [15, с. 108].

Данный момент важен прежде всего потому, что при правильной организации учебный процесс может позволить осужденному ощутить себя в новом, позитивном качестве, увлечь деятельностью, имеющей положительную, «вольную» направленность, а также способствовать развитию у него познавательных потребностей и интересов. Приобщение к общественным ценностям через образовательный процесс, а также воздействие на волю и чувства может способствовать более осознанному раскаянию людей, совершивших преступления. По словам педагогов, участие в образовательном процессе во время отбывания наказания и по освобождении из мест заключения способствует социальной интеграции. В частности, те заключенные, которые получили среднее образование в местах лишения свободы, практически не допускают рецидива преступлений [16].

В данном случае особо следует выделить значимость чтения. В 1996, 2000, 2005 гг. автор принимал участие в исследованиях, проводимых в местах лишения свободы в г. Ставрополе, в ходе которых заключенные отмечали позитивные изменения душевного состояния в результате чтения художественной литературы (хотя и упоминали об отсутствии интереса к этому занятию на свободе). В частности, библиотека Ставропольского следственного изолятора № 21/1 имеет доста- 
точно серьезную подборку художественной литературы, в том числе произведений русских и зарубежных классиков. При этом, по словам библиотекаря, востребована разная литература. Аналогичные данные приводились в проведенных в 2019 г. в Ставрополе беседах с освободившимися осужденными. Таким образом, можно выделить важную роль образования в процессе компенсации десоциализации и решении проблемы повышения эффективности процесса перевоспитания в ИТК, поскольку образование является основным средоточием нравственных ценностей, сохранение которых способствует уменьшению десоциализирующего влияния в местах лишения свободы.

Также следует отметить значимость религиозного фрактора, который помогает компенсировать десоциализацию прежде всего посредством того, что это фактор, с одной стороны, касающийся духовного состояния человека, а с другой - не несущий никакой «тюремной» окраски. Положительным является также и то, что пенитенциарная система, как правило, не препятствует работе религиозных организаций в местах лишения свободы. В частности, с 1994 г. уголовно-исполнительная система Министерства внутренних дел РФ начала тесное взаимодействие с Русской православной церковью. Министр внутренних дел и Патриарх Московский и всея Руси подписали соглашение, предусматривающее сотрудничество в области просветительной и воспитательной работы среди осуждённых [17]. Во многих регионах страны при исправительных учреждениях действуют воскресные школы, библейские курсы и иные формы обучения и религиозного просвещения заключенных. Деятельность религиозных организаций в этом направлении также поддерживает положительные изменения в духовно-нравственных ориентирах осуждённых.

Таким образом, влияние указанных факторов способно компенсировать десоциализацию осужденных при отбывании наказания в местах лишения свободы. Очевидно, что их воздействие на заключенных требуется увеличить, поэтому можно говорить о необходимости создания специальной системы работы, ориентированной прежде всего на компенсацию процесса десоциализации. Следует отметить, что сложности социальной интеграции чаще всего возникают у освободившихся из заключения в результате их неподготовленности к данному процессу. Поэтому работа, направленная на компенсацию десоциализации, должна начинаться в самих пенитенциарных учреждениях.

Отечественная пенитенциарная система, сформировавшаяся во времена СССР и практически оставшаяся без изменений до сегодняшнего дня, реализует в отношении заключенных систему исправительно-воспитательных воздействий, имеющую карательный характер [18, с. 133]. Наказание, назначенное судом, усугубляется условиями содержания, негативным отношением работников исправительного учреждения, необходимостью соответствовать нормам тюремного сообщества. Между тем очевидно, что основной целью пенитенциарного учреждения является исправление преступника, поэтому оно должно готовить человека к освобождению и жизни на свободе в соответствии с нормами общества.

С учетом выделенных фракторов можно обозначить основные черты системы работы с заключенными в направлении компенсации десоциализации в местах лишения свободы. Прежде всего, эту работу необходимо строить на доверии заключенных, поэтому к ней следует привлекать людей, не имеющих и не имевших отношения к правоохранительным органам: профессиональных психологов, социальных работников и педагогов, священнослужителей.

Проблемой может являться то, что компенсировать десоциализирующее влияние необходимо не только тем заключенным, которые хотят интегрироваться в общество, но и тем, кто не имеет такого желания (это и свидетельствует об их более глубокой десоциализации). Также установление доверительных контактов для различных заключенных требует разного количества времени; в некоторых случаях это может быть длительный процесс. В данном случае требуется понимание внутреннего мира человека, информация о его связях, наклонностях, личностных качествах.

Необходимо способствовать укреплению связей заключенных с близкими людьми, находящимися на свободе. Это может выражаться в увеличении числа и длительности свиданий, легальных телефонных разговоров. Заключенные должны иметь широкий доступ к инфрормации о том, что происходит на свободе, сведениям о рынке труда, занятости населения и связанных с этим вопросах.

Необходимо широко использовать возможности существующего в отечественной пенитенциарной системе образовательного сектора и готовности к развитию сотрудничества с религиозными организациями. Занятия в учебных заведениях позволяют заключенным провести время с пользой, помогают оптимизировать их быт, повышают самооценку. Благодаря духовному росту человек зачастую обретает способность заново переосмыслить свою жизнь, совершенные поступки.

Анализ всех перечисленных моментов дает возможность строить работу исправительных учреждений с учетом основных факторов, которые способствуют компенсации десоциализации в местах лишения свободы. Это позволит повысить эффективность процесса по исправлению и перевоспитанию заключенных. 


\section{Ссылки:}

1. Недюк М., Дагаева К. Рецидивисты стали совершать больше преступлений [Электронный ресурс] // Известия. 2017. 13 дек. URL: https://iz.ru/666795/mariia-nediuk-kseniia-dagaeva/retcidivisty-stali-sovershatbolshe-prestuplenii (дата обращения: 26.06.2020) ; Петров И. В России резко выросло количество рецидивных преступлений [Электронный ресурс] // RBC Daily. 2011. 30 марта. URL: http://www.rbcdaily.ru/2011/03/30/focus/562949979958708/ (дата обращения: 03.07.2020).

2. Гоффрман Э. Тотальные институты : очерки о социальной ситуации психически больных пациентов и прочих постояльцев закрытых учреждений / пер. с англ. А.С. Салина; под ред. А.М. Корбута. М., 2019. 458 с.

3. Барабоха Б.С. Десоциализация в местах лишения свободы: социологический анализ: дис. ... канд. социол. наук. Ставрополь, 2005. 139 с.

4. Корольков К.В. Социально-педагогический анализ воспитательно-исправительных воздействий в местах лишения свободы : дис. ... канд. пед. наук. Ставрополь, 2003. 152 с.

5. Бергер П., Лукман Т. Социальное конструирование реальности. Трактат по социологии знания / пер. Е. Руткевич. М., 1995. 323 C.

6. Корольков К.В. Указ. соч. С. 68.

7. Олейник А.Н. Тюремная субкультура: от повседневной жизни до государственной власти. М., 2017. 417 с.

8. Там же.

9. Барабоха Б.С. Указ. соч. С. 71.

10. Там же. С. 77.

11. О Концепции развития уголовно-исполнительной системы Российской Федерации до 2020 года [Электронный ресурс]: распоряжение Правительства РФ от 14 окт. 2010 г. № 1772-р (ред. от 23 сент. 2015 г.). URL: https://bazanpa.ru/pravitelstvo-rf-rasporiazhenie-n1772-r-ot14102010-h1551147/kontseptsiia (дата обращения: 02.07.2020).

12. Показатели преступности России [Электронный ресурс] // Портал правовой статистики Генеральной прокуратуры PФ. URL: http://crimestat.ru/ (дата обращения: 19.11.2016).

13. В ФСИН рассказали о росте числа заключённых, получающих высшее образование [Электронный ресурс] // Россия сегодня. 2019. 8 февр. URL: https://russian.rt.com/russia/news/ (дата обращения: 02.07.2020).

14. Положение об организации получения основного общего и среднего (полного) общего образования лицами, отбывающими наказание в виде лишения свободы в исправительных колониях и тюрьмах уголовно-исполнительной системы [Электронный ресурс]: зарегистрировано в Минюсте РФ 19 апр. 2006 г. № 7724 . Доступ из справ.-правовой системы «КонсультантПлюс» ; Порядок организации получения начального общего, основного общего и среднего общего образования лицами, отбывающими наказание в виде лишения свободы [Электронный ресурс]: утв. приказом Министерства юстиции РФ и Министерства образования и науки РФ от 6 дек. 2016 г. № 274/1525. URL: www.pravo.gov.ru (дата обращения: 03.07.2020).

15. Макаренко А.С. О коммунистическом воспитании. Избранные педагогические произведения. М., 1956. С. 108.

16. Барабоха Б.С. Указ. соч. С. 77 ; Куликов В. Число заключенных, получающих образование в колониях, выросло втрое [Электронный ресурс] // Российская газета. 2019. 8 февр. URL: https://rg.ru/2019/02/08/chislo-zakliuchennyh-poluchaiushchih-obrazovanie-v-koloniiah-vyroslo-vtroe.html (дата обращения: 03.07.2020).

17. О взаимодействии с попечительскими, общественными, религиозными и иными организациями в 2002 г. : обзор № 18-15-1-166 УВРО ГУИН Минюста России. 2002. С. 6.

18. Корольков К.В. Указ. соч. С. 133.

Редактор, переводчик: Сергейчик Людмила Ивановна 